\title{
Reducing amount and frequency of meal as a major coping strategy for food insecurity
}

\author{
Adino Tesfahun Tsegaye ${ }^{1,5^{*}}$ (D) Amare Tariku ${ }^{2,5}$, Abebaw Gebeyehu Worku ${ }^{4}$, Solomon Mekonnen Abebe ${ }^{2,5}$,
} Mezgebu Yitayal ${ }^{3,5}$, Tadesse Awoke ${ }^{1,5}$, Kassahun Alemu ${ }^{1,5}$ and Gashaw Andargie Biks 3,5

\begin{abstract}
Background: Food insecurity is a global problem affecting many people worldwide, including approximately 220 million people in sub-Saharan Africa. Ethiopia is among the countries severely affected by hunger. However, evidence on how populations within Ethiopia cope with hunger and food insecurity is limited. This study aimed to identify household coping mechanisms in response to food insecurity at a Dabat Health and Demographic Surveillance System site.

Methods: This study used data from a re-census collected between October 2014 and December 2014.15,159 household members in thirteen kebeles of the Dabat Health and Demographic surveillance system were included. The outcome variables of the study were food insecurity and coping strategies. Household Food Insecurity Access Scale (HFIAS) was used to assess food insecurity. If food insecurity was found, families were asked about coping mechanisms used. Binary logistic regression analysis was applied to identify socio-demographic determinants of reducing amount and frequency of meal as a coping mechanism in response to food insecurity.

Result: Of the 15,159 households surveyed, 6671 (44.01\%) reported the presence of a food insecurity in their household. Decreasing meal frequency and portions (3733 (55.96\%)), borrowing money and food (2542 (38.11\%)), and receiving food and money aid $(1779$ (26.67\%)) were among the major coping strategies used by the households. Urban dwellers (AOR 2.07: 95\% Cl 1.74, 2.46), mid-altitude (weyina-dega) and high-land (dega) dwellers (AOR 2.46: 95\% Cl 2.08, 2.92 and AOR 1.22 95\% Cl 1.08, 1.38 respectively), and not married persons (AOR 1.60: 95\% $\mathrm{Cl} 1.07,2.39$ ) were more likely to consume less when faced with a food insecurity (using reducing amount and frequency of meal as a coping strategy).

Conclusion: Households in the study area experienced a very high rate of food insecurity. Decreasing meal frequency and portions was the primary coping mechanism used by the households. Due to the severe insecurity of food in their household, many people chose to reduce the amount and frequency of their meal in order to prolong the small amount of food in their house. This finding indicates a high risk for undernourishment which can exacerbate the burden of malnutrition and related diseases in the region.
\end{abstract}

Keywords: Food insecurity, Coping, Reducing amount and frequency of meal, Food aid, Borrowing, Ethiopia

\footnotetext{
* Correspondence: atesfahun1@gmail.com

${ }^{1}$ Department of Epidemiology and Biostatistics, Institute of Public Health,

College of Medicine and Health Sciences, University of Gondar, Gondar,

Ethiopia

${ }^{5}$ Dabat Research Centre Health and Demographic Surveillance System,

Institute of Public Health, College of Medicine and Health Sciences,

University of Gondar, Gondar, Ethiopia

Full list of author information is available at the end of the article
}

(c) The Author(s). 2018 Open Access This article is distributed under the terms of the Creative Commons Attribution 4.0 International License (http://creativecommons.org/licenses/by/4.0/), which permits unrestricted use, distribution, and reproduction in any medium, provided you give appropriate credit to the original author(s) and the source, provide a link to the Creative Commons license, and indicate if changes were made. The Creative Commons Public Domain Dedication waiver (http://creativecommons.org/publicdomain/zero/1.0/) applies to the data made available in this article, unless otherwise stated. 


\section{Background}

Food security is a global concern and describes a state when all people, at all times, have physical and economic access to sufficient, safe and nutritious food which can meet their dietary needs $[1,2]$. Currently, food insecurity is a major challenge worldwide with $17 \%$ of people in developing countries living in extreme poverty [3]. In 2015, the Food and Agricultural Organization (FAO) reported that hunger affects 795 million people worldwide and 780 million of those people live in the world's developing regions. In sub-Saharan Africa, there were approximately 220 million hungry people in $2014-16$ (23.2\% of the population). East Africa, where Ethiopia is located, had the largest hunger burden in the region with an estimated 124 million undernourished people [4].

Many of the people most affected by hunger live in rural areas and rely on agriculture for much of their income [3]. Ensuring food security and appropriate nutrition within the poorest households is a special challenge since rural food production is limited by marginal soil fertility and a lack of resources to invest in buying the necessary agricultural inputs. In Ethiopia, more than $80 \%$ of the people live in rural areas where farming is the primary occupation. Agricultural productivity is dependent on rain and is highly vulnerable to climate change. Due to changes in weather patterns, the country has faced many droughts in recent years, which decreases crop productions and exacerbates food insecurity $[2,5]$.

The primary manifestation of food insecurity is food insecurity at the household level. As a result of food insecurity, these households face many social, economic, political and health consequences. The challenge of feeding family members has a variety of features and consequences [6] such as: migration and related health risks. Following food insecurity, people could have suicidal ideation [7], depression [8], undernutrition [9], obesity [10], diabetes mellitus [11], iron deficiency anemia [12], and deficiency of other nutrients [13]. In response to food insecurity, households use a range of mechanisms to cope.

Household coping mechanisms can vary due to season, geographic location, and other socio-economic factors [14]. A review of past literature reveals a variety of coping mechanisms used by the population during periods of food insecurity, including changing feeding habits by decreasing the amount and frequency of food intake [14-16], skipping a whole day without food [14, 15], borrowing food and money, [5, 6, 14-17], food aid [15], selling property [16], migration [5, 6], and harvesting fast-growing crops [15].

Farmers who rely on seasonal rains may also engage in other income generating activities to mitigate the risks and impacts of climate change on food security, such as owning a kiosk or small shop, selling local brews, providing traditional healing, creating artisan crafts, keeping livestock, being employed in some sectors, producing and selling natural resources (such as charcoal), and doing home gardening $[18,19]$. Some people will eat wild plants during a time of food insecurity, which may have negative health impacts $[5,20]$. The mechanism for coping with food insecurity may vary in association with marital status, household size, sex of household heads, [17] and other factors.

Despite the high level of food insecurity in Ethiopia $[21,22]$, there is limited information about coping mechanisms and the factors associated with certain coping methods used during a food insecurity particularly in the study area. Therefore, this study aims to identify and describe the coping mechanisms reported during periods of food insecurity at the Dabat Health and Demographic Surveillance System (DHDSS) site, with the intention of informing strategies to improve food security in Ethiopia. The findings of the study are expected to contribute towards filling the existing literature gap on understanding the food insecurity and coping strategies in Northwest Ethiopia. Since food security is one of the main national strategies, the findings in this study are expected to provide useful information for related policy formulation. This information is also would help to allocate resources and track the impact of interventions.

\section{Methods}

\section{Study setting and design}

The Dabat Health and Demographic Surveillance System (HDSS) site is located in Dabat District, which is a rural part of the Amhara regional state in northwest Ethiopia. Dabat HDSS is a full member of the International Network of Demographic Evaluation of Populations and Their Health (INDEPTH), a network of 44 HDSSs from the Global South. The Dabat District is located about 1000-3000 m above sea level. Dabat district was purposively selected as a surveillance site due to its unique three climatic conditions; Dega (high altitude and cold), Woina dega (mid-altitude and temperate) and Kolla (low altitude and hot). Researchers made this decision under the assumption that there would be significant differences in morbidity and mortality in the different climatic areas. After stratification of kebeles (smallest administrative units) by climatic zones, thirteen kebeles (nine rural and four urban) were selected.

Since the establishment of the Dabat HDSS site in November 1996, information on vital events has been collected every six months, with verbal autopsies (VAs) completed after reported deaths. The data used in this study was re-census data of 15,159 households in the DHDSS site that was collected between October 2014 and December 2014. All potential households in the selected kebeles were included in the data collection. The detailed data collection system, data quality control, the 
database, and the study setting of Dabat HDSS are described at the website of the University of Gondar [23].

\section{Study variables}

The outcome variables of the study were food insecurity and coping strategies. Each household was asked about the existence of food insecurity to feed the family members and the respective coping mechanisms they used in response to any such insecurity in the four week period prior to the data collection time. To assess food insecurity: access, we used Household Food Insecurity Access Scale (HFIAS). The nine questions had three domains and they produce a total score between 0 and 27 with the higher score indicating greater food insecurity. Households were categorized into food secure and insecure, and food insecure households were further categorized as mildly, moderately or severely food insecure depending on the number of positive responses to questions related to severe conditions [24]. Food insecure households were further asked about the strategy they used to cope-up with the problem. Household Hunger Scale (HHS) was also calculated by using household hunger scale measurement guide [25]. Socio-demographic factors considered in the study included the following: sex of the household head, household wealth index, place of residence, household size, marital status of household head, religion, household head's level of education, altitude/climatic zone, and household head's occupation.

\section{Data collection}

All households in nine rural kebeles and four urban kebeles from within Dabat District were contacted during the data collection period. A structured and pre-tested questionnaire was used to collect the data. The English version questionnaire was adapted and translated into Amharic, the national language. Respondents of the question were mainly females since they are culturally responsible to manage the household food. Trained and experienced HDSS site data collectors and supervisors carried out the data collection process. A total of 30 data collectors, 13 field supervisors, and 50 local guiders were recruited and involved in the data collection processes. All of the filed assistants (data collectors and supervisors) were permanent employees of the HDSS. The questionnaire was piloted outside the study area. Clarity of questions, applicability of tools, and procedures were evaluated by the pretest. To minimize recall bias, data collectors used different probing mechanisms as described in the guideline we used [24].

\section{Data management and analysis}

Data were entered in the database using the household registration system software (HRS) version 2.1, and exported to STATA 14.0 for further analysis. Households were divided into socioeconomic quartiles based on their responses. The wealth status was assessed by household $(\mathrm{HH})$ wealth index questions which were taken from the Ethiopian Demographic and Health Survey (EDHS) 2011 report [26]. It was divided into socioeconomic quantiles based on their scores. In order to capture wealth differences between urban and rural residences, the Principal Component Analysis (PCA) scores were generated for the two areas (urban and rural $\mathrm{HH}$ wealth indices) separately. In the principal component analysis, the power of the variables to explain wealth status was determined step by step using the communalities values. Those variables having communality value of greater than 0.5 were used to produce factor scores. Hence, an Eigen value of greater than one was considered. Finally, this factor scores were summed and ranked in to tertile as low, medium and better/high.

All individual descriptors collected referred to household heads, except questions regarding food insecurity, which included every member of each household $(\mathrm{HH})$. Data from15,159 HHs located in the Dabat HDSS site were used. Descriptive measures were used to present household characteristics, to measure the magnitude of food insecurity, and to identify coping strategies in the study area. Binary logistic regression analysis was used to identify socio-demographic determinants of using reducing amount and frequency of meal as a coping mechanism. We had seven household related variables and since we believe that they have public health importance, we have incorporated all of them in the model. Hosmer-Lemeshow goodness-of-fit test was used to test the overall goodness-of-fit and the $P$-value was 0.1327 (non-significant and it indicates the model was fit). Adjusted odds ratio (AOR) with 95\% confidence interval (CI) was used to report the strength of the association between reducing amount and frequency of meal and its explanatory variables.

\section{Ethical approval and consent to participate}

The HDSS site received ethical clearance from Research Ethics Review Committee of University of Gondar, Ethiopian Public Health Association (EPHA), and US Center for Disease Control and Prevention (CDC). To capture occurrence of events to any family member, the head of family or an eligible adult among the family was interviewed. At the beginning of the surveillance system in 1996, written consents were obtained from each household in the surveillance site, and additional consent was obtained from new immigrants. For the consecutive data collection periods, we just obtain informed verbal consents. For this particular study, informed verbal consent was obtained from head of the family or eligible adult among the family. This consent procedure was outlined in the proposal, 
which was approved by the ethical review committees. To maintain confidentiality, data containing personal identifiers of subjects were not shared to third party.

\section{Results}

\section{Socio-demographic characteristics of the study} participants

A total of 15,159 households participated in this study. The mean age of the household head was 45 years (standard deviation (SD) \pm 16.3 ). 10,898 (71.89\%) of the households were led by males and 9949 (65.63\%) of the participants lived in rural areas. The average family size in the area was 4.2. Agriculture was the dominant source of income in the study area (68.2\%) and the educational level of household heads is very low (Table 1).

\section{Food insecurity indicators}

Data collectors assessed for the presence of a food insecurity during the previous four week period. Out of the 15,159 households surveyed, 8488 (55.99\%) were food secure and the rest 6671 (44.01\%) were food insecure access. Out of the food insecure households, 1207 (18.09\%) were mildly food insecure, 4079 (61.05\%) were moderate, and 1385 (20.76) were severely food insecure. In addition, using HHS 14,316 (94.44\%) households had little to no hunger, 738 (4.87\%) had moderate hunger, and $105(0.69 \%)$ of the households had severe hunger.

Food insecurity had different manifestations in different households. Among all the households, 6296 $(41.53 \%)$ were forced to limit the variety of food they ate or to have repetitive diet of the same food, and in 514 (3.39\%) of the households, some individuals spent the whole day without eating at all (Table 2).

Food insecurity in households occurred with varying degrees of frequency and affected different numbers of household members. Among the 1172 households where there was a complete absence of food, in 141 (12.03\%) food was absent frequently (more than ten times per month). Some individuals in these households reported that due to a lack of food they were spending nights feeling hungry, while others were living without any food consumption for entire days. Among the 977 households in which at least one member reported feeling hungry some nights, $83(8.5 \%)$ of the households experienced this situation more than ten times per month) (Table 2).

\section{Coping strategies of household food insecurity}

Several different coping mechanisms were reported in response to the stress of household food insecurity. In DHDSS, the coping mechanisms identified were: decreasing frequency and portions of meals, borrowing food and money, receiving food and money aid, selling permanent assets, harvesting faster crops, migrating for work, engaging in labor jobs, becoming involved in small
Table 1 Socio demographic characteristics of the study, DHDSS, 2016

\begin{tabular}{|c|c|c|}
\hline Variables & Frequency & Percent \\
\hline \multicolumn{3}{|l|}{ Sex of the household head } \\
\hline Female & 4261 & 28.11 \\
\hline Male & 10,898 & 71.89 \\
\hline \multicolumn{3}{|l|}{ Residence } \\
\hline Rural & 9949 & 65.63 \\
\hline Urban & 5210 & 34.37 \\
\hline \multicolumn{3}{|l|}{ Household size } \\
\hline $1-4$ & 8711 & 57.47 \\
\hline $5-8$ & 6056 & 39.94 \\
\hline $9+$ & 392 & 2.59 \\
\hline \multicolumn{3}{|l|}{ Wealth status } \\
\hline Low income & 4293 & 28.52 \\
\hline Middle income & 5862 & 38.94 \\
\hline Better income & 4898 & 32.54 \\
\hline \multicolumn{3}{|c|}{ Marital status of household head } \\
\hline Married & 10,048 & 66.29 \\
\hline Single & 1202 & 7.93 \\
\hline Divorced & 1435 & 9.47 \\
\hline Widowed & 1901 & 12.54 \\
\hline Separated & 573 & 3.78 \\
\hline \multicolumn{3}{|l|}{ Religion } \\
\hline Orthodox & 14,574 & 96.14 \\
\hline Islam & 582 & 3.84 \\
\hline Others & 3 & 0.02 \\
\hline \multicolumn{3}{|c|}{ Household Head's level of education } \\
\hline Unable to read and write & 7428 & 49 \\
\hline Able to read and write & 3395 & 22.4 \\
\hline Primary education & 1623 & 10.71 \\
\hline Secondary education & 1764 & 11.64 \\
\hline Tertiary education & 949 & 6.26 \\
\hline \multicolumn{3}{|l|}{ Occupation } \\
\hline Student & 731 & 4.82 \\
\hline Farmer & 10,339 & 68.2 \\
\hline All types of paid job & 3345 & 22.07 \\
\hline Unemployed & 320 & 2.11 \\
\hline${ }^{\mathrm{a} O}$ Others & 424 & 2.8 \\
\hline
\end{tabular}

businesses, creating hand-made crafts, begging, and selling wood and charcoal. The most common coping mechanism employed by households in the study was to decrease the usual meal frequency and the amount of food. This strategy was used by 3733 (55.96\%) households out of the total 6671 households affected by food insecurity (Fig. 1). 
Table 2 Frequency of occurrence of behaviors, experiences, and conditions indicating food deficit and hunger in households at DHDSS, 2016

\begin{tabular}{|c|c|c|c|c|}
\hline \multirow[t]{2}{*}{ Condition } & \multicolumn{4}{|c|}{ Frequency of occurrence (percent) } \\
\hline & $\begin{array}{l}\text { Rarely } \\
\text { (1-2 times per } 4 \text { wk) }\end{array}$ & $\begin{array}{l}\text { Sometimes }(3-10 \\
\text { times per } 4 \mathrm{wk})\end{array}$ & $\begin{array}{l}\text { Many times } \\
(>10 \text { times per } 4 \text { week })\end{array}$ & $\begin{array}{l}\text { Total households } \\
\text { affected }\end{array}$ \\
\hline $\begin{array}{l}\text { Worried the family wouldn't } \\
\text { get enough food }\end{array}$ & $2078(27.7)$ & $3609(48.1)$ & $1816(24.2)$ & $7503(100)$ \\
\hline $\begin{array}{l}\text { Any of the family members } \\
\text { were not getting the food they want }\end{array}$ & 1989(30.36) & $3448(52.63)$ & 1114 [17] & $6551(100)$ \\
\hline $\begin{array}{l}\text { Any of the family members } \\
\text { forced to eat limited types of food }\end{array}$ & 1577(25.05) & $3193(50.71)$ & $1526(24.24)$ & $6296(100)$ \\
\hline $\begin{array}{l}\text { Any of the family member } \\
\text { forced to eat the food } \\
\text { they didn't want }\end{array}$ & $1441(37.4)$ & 1962(51) & 448(11.6) & $3851(100)$ \\
\hline $\begin{array}{l}\text { Any of the family members } \\
\text { forced to eat small } \\
\text { amount of food }\end{array}$ & 1667(31.1) & 2835(52.8) & $861(16.1)$ & $5363(100)$ \\
\hline $\begin{array}{l}\text { Any of the family members } \\
\text { forced to decrease meal frequency }\end{array}$ & 1816(36.2) & $2506(50.0)$ & 689(13.8) & $5011(100)$ \\
\hline $\begin{array}{l}\text { Complete absence } \\
\text { of food at home }\end{array}$ & $597(50.94)$ & 434(37.03) & $141(12.03)$ & $1172(100)$ \\
\hline $\begin{array}{l}\text { Any of the family members } \\
\text { spend nights feeling hungry }\end{array}$ & $561(57.42)$ & $333(34.08)$ & $83(8.5)$ & $977(100)$ \\
\hline $\begin{array}{l}\text { Any of the family members } \\
\text { spend the whole day without eating food }\end{array}$ & $319(62.06)$ & $147(28.06)$ & 48(9.34) & $514(100)$ \\
\hline
\end{tabular}

Many households (2542 (38.11\%)) borrowed money and/or food to cope with periods of food insecurity. Households reported asking their neighbors, friends and relatives for food and money. In some cases, households described asking local landlords and moneylenders for high-interest, short term loans. Government supported micro-finance schemes were also described.

There was a significant variation across different climatic zones in the coping mechanism they use. Twenty four percent of people who live in low-lands used borrowing food and money as a coping strategy while $14.81 \%$ and $12.01 \%$ of the mid-altitude (weyina dega) and high-landers respectively used this strategy ( $P$-value $<0.001)$. In the contrary, reducing meal frequency and amount was used by $46.05 \%$ of low-landers while $67.42 \%$ and $60.30 \%$ of mid-altitude and high-land dwellers used this strategy respectively $(P$-Value $<0.001)$. There was no statistically significant difference between other coping strategies across different climatic zones.

In this study, households experiencing food insecurity would also receive food and money aids. Food aid was received in 1779 (26.67\%) of the households, with 56 (3.15\%) receiving urgent food aid, 1094 (61.5\%) receiving safety net aid, 42 (2.36\%) receiving aid after disaster, and

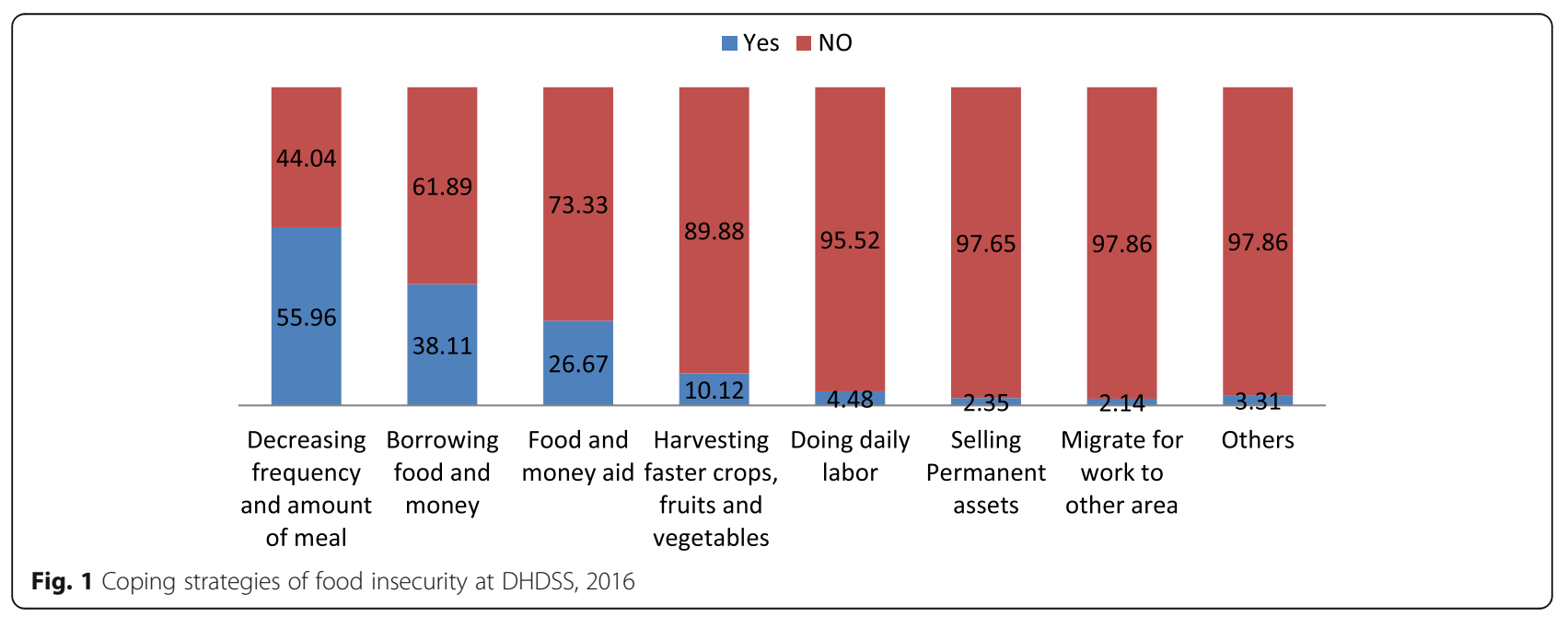


$544(30.67 \%)$ receiving aid due to aging and illness. The remaining $43(2.42 \%)$ received other aids.

Harvesting faster crops, fruits and vegetables was used by 675 (10.12\%) households who had food insecurity. This strategy was mainly used by rural residents. Out of the rural people who had food insecurity, $10.36 \%$ used this strategy while only $1.22 \%$ of the urban residents used the strategy $(P$-value $<0.001)$.

Some households used only one strategy for coping with food insecurity while others used a mix of coping mechanisms.

The most popular single coping mechanism, used in1957 (29.34\%) households, was decreasing the frequency and amount of meals. This was followed by borrowing food, which was reported by 983 (14.74\%) households. The combination of these two mechanisms was used by $680(10.19 \%)$ households.

\section{Reducing amount and frequency of meal}

Households respond to food insecurity by managing the remaining food in their home. This often includes skipping one or more of their usual meals (breakfast, lunch, or dinner). In addition, some households may manage the food they have by eating smaller amounts than they would otherwise eat. As mentioned above, among the 6671 households in DHDSS that experienced insecurity of food, $3733(55.96 \%)$ of them used this strategy as a coping mechanism. This mechanism was used by a majority of the female headed households (62.66\%) and urban dwellers (71.13\%) (Table 3).

The odds of using reducing amount and frequency of meal as a coping strategy in the face of food insecurity was 2.07 times higher among urban respondents than those who live in rural area (AOR 2.07: 95\% CI 1.74, 2.46). Households led by individuals who listed their relationship status as "separated "were 1.60 times more likely to use reducing amount and frequency of meal as a coping strategy than those led by married household heads (AOR 1.60: 95\% CI 1.07, 2.39). People who live in mid-altitude areas (weyina dega) were 2.46 times more likely to use reducing amount and frequency of meal as a coping strategy than low-land people (AOR 2.46: 95\% CI 2.08, 2.92). High-land dwellers are 1.22 times more likely to use reducing amount and frequency of meal as a coping strategy than low-land dwellers (AOR 1.22: 95\% CI 1.08, 1.38).

\section{Discussion}

This study aimed to explore food insecurity and coping mechanisms used by survey respondents in the Dabat District. Food insecurity four weeks prior to the data collection was reported by $44.01 \%$ of the households, and $36 \%$ of the households were suffering from moderate to severe food insecurity. This finding is lower than studies done in Southern Ethiopia, and South Gondar, Ethiopia [27-29]. This could be explained by the seasonal variation in collecting the data. The other studies were done in the pre harvest season when food shortage is relatively higher [30]. Many of the households that had food insecurity reported using single or multiple coping strategies to respond to the problem of lack of food. Coping strategies used included decreasing the frequency and portions of meals, borrowing food and money, receiving food and money aid, selling permanent assets, harvesting faster crops, fruits and vegetables, migrating for work to other areas, doing daily labor, becoming involved in small businesses, doing different hand crafts, begging, and selling wood and charcoal.

Decreasing meal frequency and amount was the most commonly used strategy, which coincides with studies conducted in Nigeria, Uganda and Ghana [14, 16, 17]. In response to the severe insecurity of food in their household, people often may not have other choices, and stay hungry and try to manage the small amount of food in their household. People may use this strategy over borrowing or begging, in light of low productivity and lack of work opportunities. It indicates that, the people are getting undernourished $[9,13]$ and which exacerbates the burden of malnutrition and related diseases in the area.

People who live in urban areas and people who are separated from their partners were more likely to use this coping strategy. This may be because rural dwellers have farm lands on which to harvest vegetables and other fast growing crops. In this study, harvesting fast growing crops was also a strategy mostly used by rural people. In addition, in the culture of the rural community, it is common practice to help neighbors, friends, and family in time of food insecurity. In urban areas, people are busier and may be less aware of those who need food support.

Heads of household who were living separately used this mechanism more often than married ones. Household heads who report being separated may experience less support, confidence, stability, and efficiency in their work and activities of daily living than those who report being married [31].

Borrowing food and money were also commonly used coping strategies. This is consistent with findings of previous studies conducted in Ethiopia, as well as in Nigeria, and South Africa $[5,16,17]$. When there is insecurity of food at the household level, people often borrow food or money from their neighbors or government This report of borrowing implies the presence of some richer person/lender and micro-financing schemes may also play a role in supporting people who experience food insecurity.

Receiving food and money aid was another common coping strategy. Food aid programs are helping people 
Table 3 Socio-demographic determinants of using reducing the amount and frequency of meal as a coping strategy of food insecurity at DHDSS, 2016

\begin{tabular}{|c|c|c|c|c|}
\hline \multirow[t]{2}{*}{ Variables } & \multicolumn{2}{|c|}{ Reduced the amount and frequency of meal } & \multirow[t]{2}{*}{ Crude OR(95\% Cl) } & \multirow[t]{2}{*}{ Adjusted OR(95\% Cl) } \\
\hline & Yes & No & & \\
\hline Household size (Continuous) & & & $0.93(0.90,0.95)$ & a \\
\hline \multicolumn{5}{|l|}{ Sex of the household head } \\
\hline Female & 1293(61.66) & 804(38.34) & $1.41(1.27,1.56)$ & \multirow[t]{2}{*}{ a } \\
\hline Male & $2440(53.34)$ & $2134(46.66)$ & 1 & \\
\hline \multicolumn{5}{|l|}{ Residence } \\
\hline Rural & $2585(51.12)$ & $2472(48.88)$ & 1 & \\
\hline Urban & 1148(71.13) & $466(28.87)$ & $2.36(2.08,2.66)$ & $2.07(1.74,2.46)$ \\
\hline \multicolumn{5}{|l|}{ Wealth status } \\
\hline Low income & 1440(59.8) & $968(40.2)$ & $1.28(1.13,1.46)$ & \multirow[t]{3}{*}{ a } \\
\hline Middle income & $1429(53.92)$ & $1221(46.08)$ & $1.01(0.89,1.14)$ & \\
\hline Better income & $836(53.69)$ & $721(46.31)$ & 1 & \\
\hline \multicolumn{5}{|c|}{ Household Head's level of education } \\
\hline Unable to read and write & $2249(55)$ & $1837(45)$ & 1 & \\
\hline Able to read and write & $807(53.2)$ & $710(46.8)$ & $0.93(0.82,1.04)$ & \multirow[t]{4}{*}{ a } \\
\hline Primary education & $326(58.63)$ & $230(41.37)$ & $1.16(0.97,1.38)$ & \\
\hline Secondary education & $301(68.72)$ & 137(31.28) & $1.79(1.45,2.22)$ & \\
\hline Tertiary education & $50(67.57)$ & $24(32.43)$ & $1.70(1.04,2.78)$ & \\
\hline \multicolumn{5}{|c|}{ Marital status of household heads } \\
\hline Married & $2281(52.58)$ & $2057(47.42)$ & 1 & 1 \\
\hline Single & $230(69.49)$ & $101(30.51)$ & $2.05(1.61,2.61)$ & $1.21(0.82,1.78)$ \\
\hline Divorced & $522(64.29)$ & 290(35.71) & $1.62(1.39,1.89)$ & $1.22(0.92,1.61)$ \\
\hline Widowed & $578(56.72)$ & $441(43.28)$ & $1.18(1.03,1.36)$ & $1.04(0.79,1.37)$ \\
\hline Separated & $122(71.35)$ & $49(28.65)$ & $2.25(1.60,3.14)$ & $1.60(1.07,2.39)$ \\
\hline \multicolumn{5}{|l|}{ House hold head's occupation } \\
\hline Farmer & $2706(52.56)$ & $2442(47.44)$ & 1 & \\
\hline Student & 178(69.53) & $78(30.47)$ & $2.06(1.57,2.70)$ & \multirow[t]{4}{*}{ a } \\
\hline All types of paid job & 643(69.66) & $280(30.34)$ & $2.07(1.78,2.41)$ & \\
\hline Unemployed & $81(65.32)$ & 43(34.68) & $1.70(1.17,2.47)$ & \\
\hline Others & $125(56.82)$ & $95(43.18)$ & $1.18(0.90,1.56)$ & \\
\hline \multicolumn{5}{|l|}{ Climatic Zone } \\
\hline Hot/Lowland & 1120 & 1312 & 1 & 1 \\
\hline Mid-altitude & 540 & 261 & $2.42(2.05,2.87)$ & $2.46(2.08,2.92)$ \\
\hline Cold/Highland & 2073 & 1365 & $1.78(1.60,1.98)$ & $1.22(1.08,1.38)$ \\
\hline
\end{tabular}

${ }^{a}$ Not statistically significant

get relief from hunger [32]. Harvesting fast growing crops such as vegetable and fruit gardens, seeking work as daily labor, and selling permanent assets are coping strategies that have considerably contributed to alleviating food insecurity.

Climatic zone had a significant effect in the coping strategies people use. People who were living in lower altitudes (Kola) were more likely to use borrowing as a coping strategy while the mid-altitude (Weyina-dega) and high-landers (dega) were more likely to use reducing meal amount and frequency as a coping strategy. This might happen due to low-lands are more easily accessible, more cultivatable, and more productive [6]; and people who have food insecurity in low-lands could have better chance to get an assistance from their neighborhoods [33], and to sell the property they have than to reduce the amount and frequency of their meal.

The high burden of food insecurity in these populations needs critical attention to prevent its social, economic, political, and health impacts. With the existing high burden of malnutrition in Ethiopia [34], the high burden of food insecurity and using reducing the amount and frequency of meal as a major coping strategy would bring a big burden on the country. It increases 
malnutrition and related infectious and non-infectious diseases [35, 36]; decrease productivity [37]; decrease school attendance and educational attainment [38]; and thereby it affects the growth and development of the country $[39,40]$. It shows how working on food security is crucial and very important.

Therefore; targeted activities are recommended in order to alleviate the burden of food insecurity in this area. Measures to increase land productivity may be helpful for households in rural areas. In addition to fast growing crops and vegetables, using irrigation is also recommended to increase land productivity. To decrease dependency on crop production, it would be beneficial to invest in other kinds of farming, such as poultry, honey, and diary. Micro finance schemes should be strengthened, to improve access to saving and lending at the household level. Finally, increased access to job opportunities, especially in the urban area where there is little land to harvest, would minimize the negative impacts of food insecurity.

Although this study showed a representative sample of households in the Dabat district, and is assumed to represent the larger area of northwest Ethiopia, there are limitations worth highlighting. We believe that gathering additional data using qualitative methods could strengthen our findings by providing deep exploration into the ways in which households respond and cope with food insecurity.

\section{Conclusion}

Food insecurity in the study area was very high. In the response to a food insecurity, households reported using various coping strategies which included decreasing meal frequency and portions (reducing amount and frequency of meal), borrowing food and money, receiving food and money aid, selling permanent assets, harvesting faster crops, migration of the household head in search of work, involvement in daily labor, getting involved in small business activities, making and selling hand crafts, begging, and selling wood and charcoal Decreasing meal frequency and portions or reducing amount and frequency of meal was the most commonly reported coping mechanism and it was significantly associated with residence and marital status. During times of severe insecurity of food in their households, people preferred to stay hungry in order to manage the small amount of food they had. This is an indicator that people may become undernourished, which may exacerbate the burden of malnutrition and other related diseases in the area.

\section{Acknowledgments}

We would like to thank the University of Gondar, CDC US, and Ethiopian Public Health Association for the financial support as well as the data collectors who participated in this study for their commitment. We also like to thank Kate Pfizenmaier for her unreserved support in editing the language.

\section{Funding}

The study was funded by PEPFAR - Centers for Disease Control and Prevention (CDC) through Ethiopian Public Health Association (EPHA) in accordance with the EPHA-CDC Cooperative Agreement No.

NU22GGH001039-04-00 and University of Gondar.

Availability of data and materials

All data supporting our findings will be shared upon request.

\section{Authors' contributions}

$A T$ and $G A B$ conceived the idea and the research designed by $A T T, G A B$, and $K A$. GAB, AT, ATT, AGW, SMA, MY, TA, and KA coordinate the process. $A T$ and GAB analyzed the data. Wrote the paper: AT, GAB, and KA. All authors read and approved the final manuscript.

\section{Ethics approval and consent to participate}

The HDSS site received ethical clearance from Research Ethics Review Committee of University of Gondar, Ethiopian Public Health Association (EPHA), and US Center for Disease Control and Prevention (CDC). To capture occurrence of the events to any family member, head of a family or an eligible adult among the family was interviewed. At the beginning of the surveillance system in 1996, written consents were obtained from each household in the surveillance site, and it is also done when there exists new immigrant. After that for consecutive data collection periods, we just obtain informed consents. Therefore; for this particular study, informed verbal consent was obtained from head of the family or eligible adult among the family. This consent procedure was stated in the proposal which was approved by the ethical review committees. To keep confidentiality, data containing personal identifiers of subjects were not shared to third party.

\section{Consent for publication}

Not applicable.

\section{Competing interest}

We declared that none of the authors have any competing interests in the manuscript.

\section{Publisher's Note}

Springer Nature remains neutral with regard to jurisdictional claims in published maps and institutional affiliations.

\section{Author details}

'Department of Epidemiology and Biostatistics, Institute of Public Health, College of Medicine and Health Sciences, University of Gondar, Gondar, Ethiopia. ${ }^{2}$ Department of Human Nutrition, Institute of Public Health, College of Medicine and Health Sciences, University of Gondar, Gondar, Ethiopia. ${ }^{3}$ Department of Health Service Management and Economics, Institute of Public Health, College of Medicine and Health Sciences, University of Gondar, Gondar, Ethiopia. ${ }^{4}$ Department of Reproductive Health, Institute of Public Health, College of Medicine and Health Sciences, University of Gondar, Gondar, Ethiopia. ${ }^{5}$ Dabat Research Centre Health and Demographic Surveillance System, Institute of Public Health, College of Medicine and Health Sciences, University of Gondar, Gondar, Ethiopia.

Received: 22 December 2017 Accepted: 7 August 2018

Published online: 04 October 2018

\section{References}

1. FAO. Declaration on world food security. Rome: World Food Summit; 1996.

2. Sasson A. Food security for Africa: an urgent global challenge. Agriculture \& Food Security. 2012;1(2):1-16.

3. World Bank. Povcalnet. Online analysis tool for global poverty monitoring. 2015 http://iresearch.worldbank.org/PovcalNet/index.htm.

4. FAO laW. The State of Food Insecurity in the World 2015. In: Meeting the 2015 international hunger targets: taking stock of uneven progress. Rome: FAO; 2015.

5. Derribew A. An assessment of coping strategies for drought induced food Shortages in Fedis District, east Hararghe zone. Ethiopia Int J Sci Res (IJSR). 2015;4(1):289-94. 
6. KHATRI-CHHETRI A, MAHARJAN KL. Food insecurity and coping strategies in rural areas of Nepal a Case study of Dailekh District in mid western development region. J Int Dev Coop. 2006;12(2):25-45.

7. Davison KM, Marshall-Fabien GL, Tecson A. Association of moderate and severe food insecurity with suicidal ideation in adults: national survey data from three Canadian provinces. Soc Psychiatry Psychiatr Epidemiol. 2015;50(6):963-72.

8. Ramsey R, Giskes K, Turrell G, Gallegos D. Food insecurity among adults residing in disadvantaged urban areas: potential health and dietary consequences. Public Health Nutr. 2012;15(2):227-37.

9. Psaki S, Bhutta ZA, Ahmed T, Ahmed S, Bessong P, Islam M, et al. Household food access and child malnutrition: results from the eight-country MAL-ED study. Popul Health Metrics. 2012;10(24):1-11.

10. Pan $L$, Sherry B, Njai $R$, Blanck HM, Metrics P. To read this article in full, please review your options for gaining access at the bottom of the page. Food insecurity is associated with obesity among US adults in 12 states. J Acad Nutr Diet. 2012;112(9):1403-9.

11. Seligman HK, BindmanEric AB, VittinghoffAlka, Kanaya M, Kushel MB. Food insecurity is associated with diabetes mellitus: results from the National Health Examination and nutrition examination survey (NHANES) 1999-2002. J Gen Intern Med. 2007;22(7):1018-23.

12. Ke J, Ford-Jones EL. Food insecurity and hunger: a review of the effects on children's health and behaviour. Paediatr Child Health. 2015;20(2):89-91.

13. Lee JS, Edward A, Frongillo J. Nutritional and Health Consequences Are Associated with Food Insecurity among U.S. Elderly Persons. J Nutr. 2001;131(5):1503-9.

14. Chagomoka T, Unger S, Drescher A, Glaser R, Marschner B, Schlesinger J. Food coping strategies in northern Ghana. A socio-spatial analysis along the urban-rural continuum. Agric Food Secur. 2016;5(4):334-42.

15. Wabwoba MS, Wakhungu JW, Omuterema S. Household food insecurity coping strategies in Bungoma County. Kenya Int J Nutr Food Sci. 2015;4(6):713-6.

16. Ngidi MS, Hendriks SL. Coping with food insecurity in rural South Africa: the Case of Jozini. KwaZulu-Natal Mediterranean J Soc Sci. 2014;5(25):278-89.

17. Rebecca AA, Ige AS. Determination of farmers' coping strategies to household food insecurity in Oyo state. Nigeria Am J Soc Manag Sci. 2013;4(1):1-7.

18. Daninga PD, Ke W. Coping Strategies toward Food Security. A Case of Morogoro Region J Econ Sustain Dev. 2014;5(28):26-33.

19. Cofie OO, Veenhuizen Rv, Drechsel P. CONTRIBUTION OF URBAN AND PERIURBAN AGRICULTURE TO FOOD SECURITY IN SUB-SAHARAN AFRICA International Water Management Institute (IWMI) Paper to be presented at the Africa session. 2003. https://www.alnap.org/system/files/content/ resource/files/main/contribution-ua-food-security.pdf.

20. E. M, Zvikomborero, Chigora P. An analysis of the coping strategies arising out of food SHORTAGES in ZIMBABWE: a CASE of CHITSE and KAMUTSEDZERE wards of MT DARWIN district from 2007-2008. J Sustain Dev in Africa 2010;12(2):1-34.

21. WFP and CSA. Comprehensive food security and Vulnerability Analysis in Ethiopia. Ethiopia: Addis Ababa; 2014. https://documents.wfp.org/stellent/ groups/public/documents/ena/wfp265490.pdf?_ga=1.226661405. 1837315268.1472838579

22. WFP and Famine Early Warning Systems Network. ETHIOPIA Food Security Outlook Update. 2017. http://fews.net/east-africa/ethiopia/food-securityoutlook-update/august-2017.

23. University of Gondar. Profile of Dabat Health and Demographic Surveillance System/Dabat Research Center. Gondar: University of Gondar; 2012.

24. Coates J, Swindale A, Bilinsky P. Household food insecurity access scale (HFIAS) for measurement of household food access: Indicator guide (v. 3). Food and Nutrition Technical Assistance Project, Academy for Educational Development: Washington, D.C; 2007.

25. Ballard T, Coates J, Swindale A, Deitchler M. Household Hunger Scale: Indicator Definition and Measurement Guide Washington, DC: Food and Nutrition Technical Assistance II Project, FHI 360.2011.

26. Central Statistical Agency. Ethiopian Demographic and Health Survey. 2011.

27. Endale W, Mengesha ZB, Atinafu A, Adane AA. Food Insecurity in Farta District, Northwest Ethiopia: a community based cross-sectional study. BMC Research Notes. 2014;7:130.

28. Regassa N. Small holder farmers coping strategies to household food insecurity and hunger in southern Ethiopia Ethiopian Journal of environmental studies and. Management. 2011;4(1):39-48.

29. Regassa N, Stoecker BJ. Household food insecurity and hunger among households inSidama district, southern Ethiopia. Public Health Nutr. 2011;15(7):1276-83.
30. Tolossa D. Causes of Seasonal Food Insecurity in Oromiya Zone of Amhara Region: Farmers' View. In: International, Conference on African Development Archives. Paper 36; 2001. http://scholarworks.wmich.edu/africancenter_icad_ archive/36.

31. MartinLindström, Rosvall M. Marital status, social capital, economic stress, and mental health: a population-based study. Soc Sci J. 2012;49(3):339-42.

32. Devereux S. FOOD INSECURITY IN ETHIOPIA A discussion paper for DFID. 2000. https://www.ids.ac.uk/files/FoodSecEthiopia4.pdf.

33. Asmamaw T, Budusa M, Teshager M. Analysis of vulnerability to food insecurity in the Case of Sayint District. Ethiopia Asian J Rural Dev. 2015;5(1):1-11.

34. Central Statistical Agency. Ethiopian Demographic and Health Survey. 2016.

35. Guerrant RL, Oriá RB, Moore SR, Oriá MO, Lima AA. Malnutrition as an enteric infectious disease with long-term effects on child development. Nutr Rev. 2008;66(9):487-505

36. Hadley C, Tegegn A, Tessema F, Cowan JA, Asefa M, Galea S. Food insecurity, stressful life events and symptoms of anxiety and depression in East Africa: evidence from the Gilgel gibe growth and development study. J Epidemiol Community Health. 2008;62:980-6.

37. Ross JCC, He W, Fu G, Wang YY, Fu ZY, Chen MX. Effects of malnutrition on economic productivity in China as estimated by PROFILES. Biomed Environ Sci. 2003;16(3):195-205.

38. Belachew T, Hadley C, Lindstrom D, Gebremariam A, Lachat C, Kolsteren P. Food insecurity, school absenteeism and educational attainment of adolescents in Jimma Zone Southwest Ethiopia: a longitudinal study. Nutrition Journal. 2011;10:29.

39. Freijer K, Tan SS, A. Koopmanschap M, M.M.Meijers J, J.G.Halfens R, J.C. Nuijtene M. The economic costs of disease related malnutrition. Clin Nutr 2013;32(1):136-141.

40. Bain LE, Awah PK, Geraldine N, Kindong NP, Sigal Y, Bernard N, et al. Malnutrition in Sub - Saharan Africa: burden, causes and prospects. Pan African Medical Journal. 2013:15:120.

\section{Ready to submit your research? Choose BMC and benefit from:}

- fast, convenient online submission

- thorough peer review by experienced researchers in your field

- rapid publication on acceptance

- support for research data, including large and complex data types

- gold Open Access which fosters wider collaboration and increased citations

- maximum visibility for your research: over $100 \mathrm{M}$ website views per year

At $\mathrm{BMC}$, research is always in progress.

Learn more biomedcentral.com/submissions 